\title{
Increase of serum leptin after short-term pulsatile GnRH administration in children with delayed puberty
}

\author{
Corinna Grasemann, Hendrika T Wessels, Sabine Knauer-Fischer, Annette Richter-Unruh and Berthold P Hauffa \\ Department of Haematology, Oncology and Endocrinology, Children's Hospital, University of Essen, Hufelandstrasse 55, 45122 Essen, Germany \\ (Correspondence should be addressed to C Grasemann; Email: corinna.grasemann@medizin.uni-essen.de)
}

\begin{abstract}
Objective: Leptin is known to play an important role in pubertal development in humans, probably acting as one permissive factor for the onset of puberty. Leptin serum concentrations change during pubertal development and an initial increase before the onset of puberty has been reported. The underlying mechanism for this increase in leptin levels is unknown. We hypothesized that the pulsatile release of GnRH stimulates leptin metabolism. In this study, the effect of short-term pulsatile GnRH administration on leptin levels in children with delayed onset of puberty was investigated. Methods: Nineteen children (15 males and four females, mean age 15.5 years, range 13.1-20.5 years), who underwent evaluation for delayed sexual maturation, were included in the study. Sixteen subjects received $36 \mathrm{~h}$ of pulsatile intravenous $\mathrm{GnRH}$, using an infusion pump that released $5 \mu \mathrm{g}$ GnRH every $90 \mathrm{~min}$. Serum concentrations of LH, FSH, testosterone, estradiol and leptin were analysed before and up to $36 \mathrm{~h}$ after $\mathrm{GnRH}$ administration. Eight patients received a single dose GnRH-agonist stimulation test (buserelin acetate test, $10 \mu \mathrm{g} / \mathrm{kg}$ body weight) with a 24 -h followup (five patients underwent both tests).

Results: Mean $( \pm$ S.E.M.) serum leptin increased significantly $(P<0.01)$ after $36 \mathrm{~h}$ of pulsatile GnRH administration $(7.26 \pm 1.35$ vs $9.75 \pm 1.76 \mathrm{ng} / \mathrm{ml})$. In contrast, no increase in leptin concentrations was observed after administration of a single dose of buserelin.

Conclusions: These findings suggested that the increase in serum leptin at the onset of puberty is triggered by the pulsatile release of GnRH.
\end{abstract}

European Journal of Endocrinology 150 691-698

\section{Introduction}

Leptin, the product of the $o b$ gene (1), is mainly produced by adipose tissue. Serum leptin concentrations are therefore positively correlated with the amount of body fat and body mass index (BMI). The hormone is thought to signal nutritional status to the hypothalamus and pituitary, resulting in suppression of appetite and stimulation of energy expenditure at the hypothalamic level $(2-4)$. Furthermore, leptin plays an important role in pubertal development. Subjects with mutations in the leptin or leptin receptor gene are infertile due to hypogonadotropic hypogonadism and develop severe obesity early in life $(5-7)$. Treatment with recombinant leptin resulted in weight loss and a pubertal pattern of luteinizing hormone (LH) release in a 12-year-old girl with congenital leptin deficiency (8). It has been shown that a critical amount of leptin or leptin signaling is required for the onset of pubertal development. Furthermore, a decline in leptin levels below a critical concentration, e.g. in patients with anorexia nervosa, results in a condition resembling 'reversed puberty' with hypogonadotropic hypogonadism (9). Up to now leptin has been thought to act as a permissive factor for the onset or progression of puberty rather than initiating puberty itself (10).

Many investigators have found an influence of gender and pubertal stage on circulating leptin concentrations in humans $(11-15)$. While leptin concentrations do not differ in prepubertal boys and girls, a sexual dimorphism develops with pubertal progression. In female puberty, leptin concentrations steadily increase whereas in male puberty leptin concentrations only increase until approximately the age of 10 years, and than decrease with increasing testosterone levels (16). This is explained by an inhibitory effect of testosterone on leptin (17). Interestingly, it has been shown that leptin levels peak before the onset of puberty in both sexes, suggesting a specific role for leptin at this point of puberty $(12,14)$. It remains unclear why leptin concentrations increase directly before the onset of puberty and whether this increase is essential for pubertal development.

We hypothesized that the observed peak in serum leptin concentrations is mediated by changes in other hormones involved in pubertal development. As in 
normal human puberty an increase in the amplitude of pulsatile gonadotropin secretion during sleep (18) marks the hormonal onset of puberty, we investigated the effect of pulsatile gonadotropin-releasing hormone $(\mathrm{GnRH})$ administration on leptin profiles in children and adolescents with constitutional delay of puberty (CD) or hypogonadotropic hypogonadism (HH).

\section{Subjects and methods}

\section{Subjects}

A total of 19 children and adolescents with delayed sexual maturation (15 male and four female) with a mean \pm S.E.M. age of $15.5 \pm 0.2$ years (range 13.120.5 years) were included in the study. Eight subjects were diagnosed with $\mathrm{HH}$ and eleven had CD. Diagnoses were based on the results of a 36-h pulsatile GnRHstimulation test as described by Smals et al. (19). The main characteristics of the study population are shown in Table 1. Comparisons between patients with $\mathrm{HH}$ and $\mathrm{CD}$ revealed no significant differences in gender distribution, age, bone age, BMI and serum leptin levels (Table 1). Serum concentrations of LH, as expected, were significantly higher in the group of patients with $\mathrm{CD}(P=0.016)$.

All patients were admitted to hospital for further evaluation of the hypothalamic-pituitary-gonadal axis after initial evaluation in our outpatient department. Parents were informed and gave permission for the procedures. Of the 19 patients, eight underwent the single dose GnRH test (buserelin acetate test) and 16 underwent testing with pulsatile gonadotropin. Five out of the 16 received the single dose $\mathrm{GnRH}$ test (buserelin acetate test) in addition to the 36-h stimulation test and three patients underwent the buserelin acetate test only.

\section{Protocol}

The patients underwent testing with pulsatile $\mathrm{GnRH}$ stimulation for $36 \mathrm{~h}$ and/or a single dose busereline

Table 1 Characteristics of the study population. Values are means \pm S.E.M. with range in parentheses.

\begin{tabular}{lcc}
\hline & HH $(n=8)$ & CD $(n=11)$ \\
\hline Gender (female/male) & $2 / 6$ & $2 / 9$ \\
Age (years) & $16.2 \pm 0.7$ & $15.5 \pm 0.2$ \\
& $(13.1-20.5)$ & $(14.7-16.6)$ \\
Bone age (years) & $13.4 \pm 1.2$ & $13.5 \pm 0.2$ \\
& $(9.8-20)$ & $(12.6-14.6)$ \\
BMI $\left(\mathrm{kg} / \mathrm{m}^{2}\right)$ & $21.5 \pm 1.4$ & $22.0 \pm 1.3$ \\
& $(17-29)$ & $(16-30)$ \\
LH $(\mathrm{U} / \mathrm{l})$ before stimulation test & $0.34 \pm 0.13$ & $2.8 \pm 0.62$ \\
& $(0.03-1.08)$ & $(0.3-7)$ \\
FSH $(\mathrm{U} / \mathrm{l})$ before stimulation test & $1.2 \pm 2.9$ & $3.5 \pm 0.6$ \\
& $(0.18-2.43)$ & $(1.4-8.4)$ \\
Leptin $(\mathrm{ng} / \mathrm{ml})$ before stimulation test & $8.6 \pm 2.3$ & $6.3 \pm 1.6$ \\
& $(1.5-22.4)$ & $(0.79-17.7)$ \\
\hline
\end{tabular}

acetate test for further evaluation of the hypothalamic-pituitary axis. These tests are standard procedures to differentiate between CD and HH (19).

\section{Pulsatile GnRH stimulation for $36 \mathrm{~h}$}

All patients were admitted to hospital the day before testing (day 0). An indwelling i.v. catheter was placed in an antecubital vein. Blood was drawn from this catheter throughout the study period. On day 1 a standard $\mathrm{GnRH}$ bolus test, using $25 \mu \mathrm{g} \mathrm{GnRH} / \mathrm{m}^{2}$ body surface area (Relefact LHRH; Aventis Pharma, Bad Soden, Germany), was performed starting at $0900 \mathrm{~h}$. Blood samples for $\mathrm{LH}$, follicle-stimulating hormone (FSH) and leptin determination were drawn from the indwelling catheter at $0,10,20,30,60$ and $120 \mathrm{~min}$ after the GnRH i.v. bolus. At $1800 \mathrm{~h}$ on day 1 a miniaturized infusion pump (Zyklomat; Ferring, Kiel, Germany) was connected to the i.v. catheter. This pump delivers $5 \mu \mathrm{g}$ GnRH every $90 \mathrm{~min}$ for a period of $36 \mathrm{~h}$. On day 3 the infusion pump was disconnected at $0600 \mathrm{~h}$ and the standard GnRH bolus test was repeated at $0900 \mathrm{~h}$. A flow sheet of the procedures performed is shown in Fig. 1.

\section{Buserelin acetate test}

Eight children underwent a single-dose stimulation with a GnRH agonist (buserelin acetate) with a 24-h follow-up of serum concentrations of LH, FSH, testosterone, estradiol and leptin. In the five children who underwent the pulsatile GnRH stimulation and the buserelin acetate test, the second test was started at least 4 weeks after the first one. Patients were admitted to hospital on day 0 and an indwelling i.v. catheter was placed in an antecubital vein. The buserelin acetate test started on day 1 at $0800 \mathrm{~h}$ with an intramuscular injection of buserelin acetate $(10 \mu \mathrm{g} / \mathrm{kg}$ body weight; Profact; Aventis Pharma). Blood samples for LH, FSH, testosterone, estradiol and leptin determination were drawn from the indwelling catheter at 0, 2, 4, 8, 12 and $24 \mathrm{~h}$ after the injection.

\section{Hormone assays}

Serum LH and FSH levels were measured using a specific RIA (Perkin Elmer, Turku, Finland). The LH test had an analytical sensitivity of $0.05 \mathrm{U} / \mathrm{l}$. Intraand interassay variation coefficients at $0.3 \mathrm{U} / \mathrm{l} \mathrm{LH}$ were 9.4 and $2.6 \%$ respectively. The analytical sensitivity of FSH was $0.05 \mathrm{U} / \mathrm{l}$. The intra- and interassay coefficients of variation for $\mathrm{LH}$ at $2.56 \mathrm{U} / \mathrm{l}$ were 1.4 and $3.1 \%$ respectively.

Serum levels of testosterone were measured by RIA (DPC, Los Angeles, CA, USA). Intra- and interassay coefficients were 7 and $11 \%$ (at $2.64 \mathrm{nmol} / \mathrm{l}$ ) respectively. The lower limit of detection was $0.14 \mathrm{nmol} / \mathrm{l}$. 


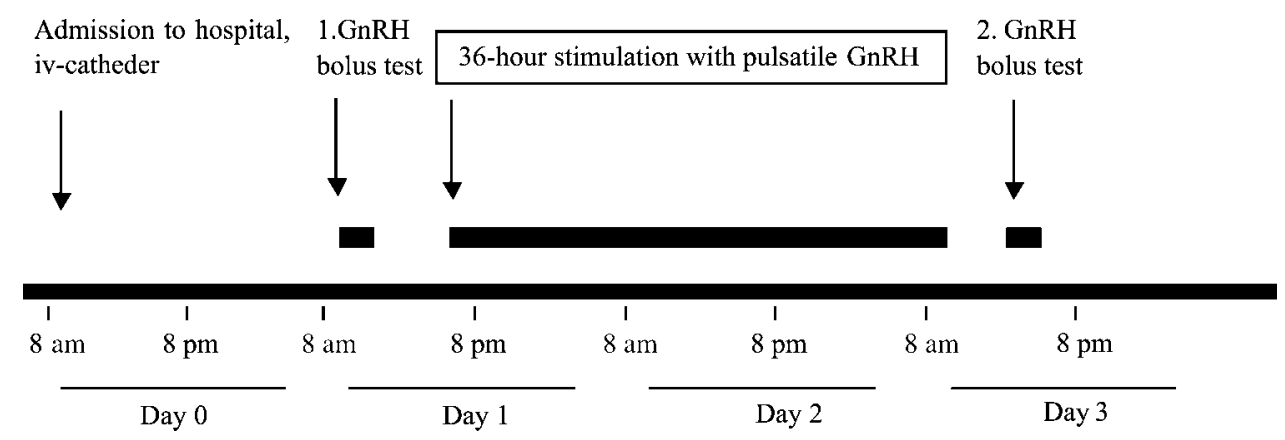

Figure 1 Administration of $\mathrm{GnRH}$ in patients undergoing the 36-h $\mathrm{GnRH}$ stimulation test. In the $\mathrm{GnRH}$ bolus tests, $25 \mu \mathrm{g}$ GnRH/m ${ }^{2}$ body surface was administered and blood samples were collected 0, 10, 20,30, 60 and 120 min after the bolus. During the $36 \mathrm{~h}$ of pulsatile $\mathrm{GnRH}$ administration a pump delivered $5 \mu \mathrm{g} \mathrm{GnRH}$ every $90 \mathrm{~min}$.

Estradiol was measured using a specific RIA (Dia Sorin, Saluggia, Italy). The assay sensitivity was below $18.4 \mathrm{pmol} / \mathrm{l}$. Intra- and interassay coefficients of variation were $4.2 \%$ (at $110 \mathrm{pmol} / \mathrm{l}$ ) and $4.9 \%$ (at $294 \mathrm{pmol} / \mathrm{l}$ ) respectively. Serum concentrations of testosterone and estradiol were measured before and after the pulsatile GnRH stimulation.

Total human leptin was measured by RIA as described (24) (human leptin kit; Linco Research, St Charles, MO, USA). Intra- and interassay coefficients were 4.6 and $5.0 \%$ (at $7.2 \mathrm{ng} / \mathrm{ml}$ ) and 4.7 and $3.0 \%$ (at $15.7 \mathrm{ng} / \mathrm{ml}$ ) respectively. The lower limit of detection was $0.5 \mathrm{ng} / \mathrm{ml}$. Samples were measured in duplicate twice.

\section{Statistical analysis}

Intra-individual comparisons of hormone concentrations were performed with the Wilcoxon repeated sample test. The effect of pulsatile GnRH administration and further variables, such as initial diagnosis, BMI, estradiol, testosterone or gonadotropin concentrations, was analysed by multiple stepwise regression using the GLM procedure of SAS (V 6.12; SAS, Carey, NJ, USA). Values are given throughout as means \pm S.E.M.

\section{Results}

\section{Pulsatile GnRH stimulation for $36 \mathrm{~h}$}

The 36-h pulsatile GnRH stimulation was preceded and followed by a standard GnRH stimulation test. In these standard GnRH tests hormonal changes in the serum were monitored during a 120-min follow-up at the time-points $0,10,20,30,60$ and $120 \mathrm{~min}$ after the bolus (see Subjects and methods for details). As expected, serum levels of gonadotropins increased during the $120 \mathrm{~min}$ of these standard GnRH tests in patients with $\mathrm{CD}$ and in patients with $\mathrm{HH}$. In patients with $\mathrm{CD}$, mean LH serum levels increased from $2.86 \pm 0.62$ to $7.03 \pm 1.61 \mathrm{U} / \mathrm{l}$ after $120 \mathrm{~min}$, and mean serum levels of FSH increased from 3.69 \pm 0.62 to $4.64 \pm 0.42 \mathrm{U} / \mathrm{l}$ after $120 \mathrm{~min}$. In patients with $\mathrm{HH}$, mean LH serum levels increased from $0.34 \pm 0.13$ to $1.39 \pm 0.28 \mathrm{U} / \mathrm{l}$ after $120 \mathrm{~min}$, and mean serum levels of FSH increased from $1.2 \pm 0.3$ to $2.5 \pm 0.4 \mathrm{U} / \mathrm{l}$ after $120 \mathrm{~min}$. Peak levels of LH and FSH were observed $30 \mathrm{~min}$ after the GnRH bolus. Serum leptin concentrations remained unchanged over the 120-min follow-up in the standard GnRH tests (data not shown).

However, comparison between the first and the second standard GnRH test showed significantly higher leptin concentrations in the second GnRH test, but no significant changes in serum levels of LH, FSH or estradiol (Fig. 2). Leptin serum concentrations were elevated throughout the second GnRH test at all time-points $(0,10,20,30,60$ and $120 \mathrm{~min}$ after the GnRH bolus). In the following text and in the tables only the baseline values (time-point 0 ) of the first and second standard GnRH test are used to allow easier comparison between hormone levels before and after the GnRH pump. Hormonal changes for all timepoints during the standard GnRH tests are displayed in Fig. 3.

Mean serum leptin concentrations in the 16 patients who underwent pulsatile stimulation with $\mathrm{GnRH}$ increased significantly from $7.26 \pm 1.35 \mathrm{ng} / \mathrm{ml}$ in the first $\mathrm{GnRH}$ test to $9.75 \pm 1.76 \mathrm{ng} / \mathrm{ml}$ in the second test $(P<0.01$, Wilcoxon repeated sample test $)$. This increase in serum leptin concentrations was observed in every patient and was significant in both groups, children with $\mathrm{HH}(P=0.014)$ and children with $\mathrm{CD}$ $(P=0.025$, Wilcoxon repeated sample test $)$. There was no difference in the leptin response between male and female patients. Mean serum concentrations of LH increased from $1.91 \pm 0.46$ to $3.07 \pm 0.94 \mathrm{U} / \mathrm{l}$ (not significant) after the pump and mean FSH concentrations increased from $2.7 \pm 05$ to $3.7 \pm 0.4 \mathrm{U} / \mathrm{l}$ (not significant). Changes in baseline serum concentrations of leptin, LH, FSH, estradiol and testosterone are displayed in Fig. 2.

Serum levels of testosterone increased in most patients after the GnRH priming. Mean serum concentrations increased from $3.15 \pm 1$ to $5.06 \pm 2.15 \mathrm{nmol} / \mathrm{l}$ (not significant). Mean serum concentrations of 


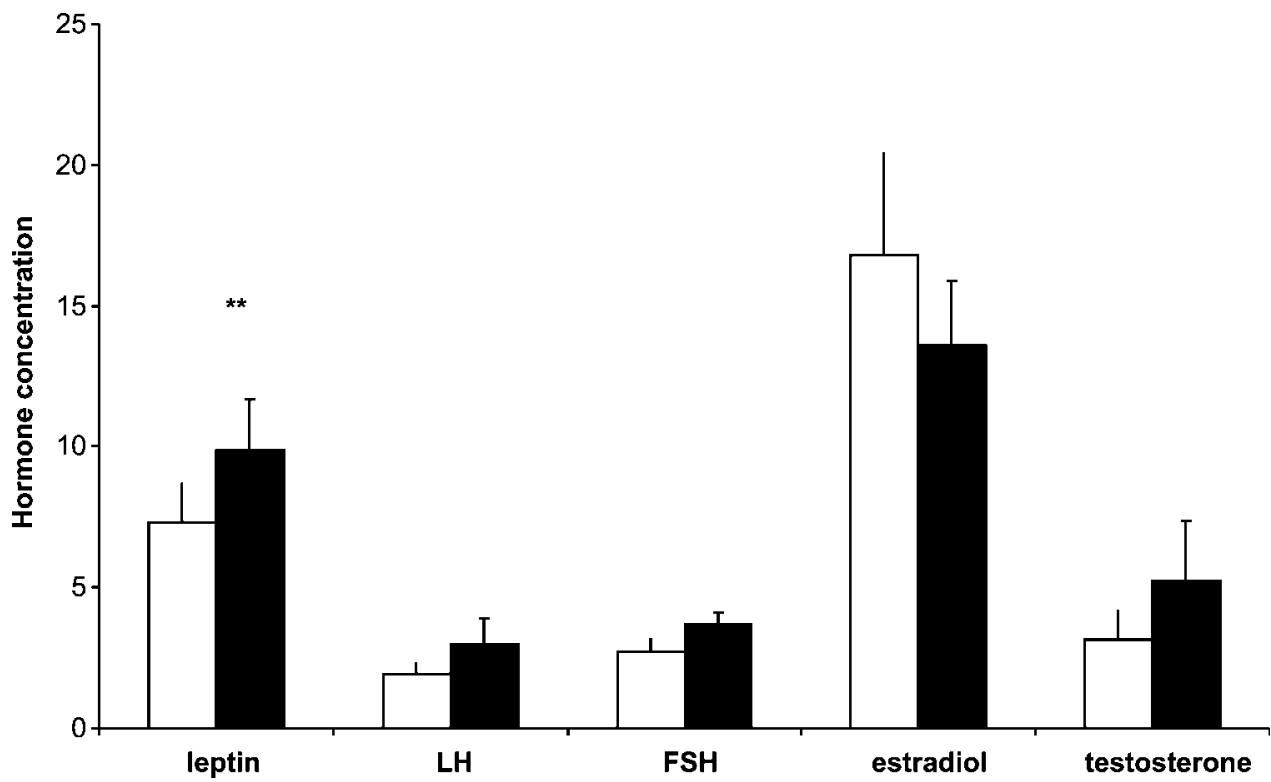

Figure 2 Serum concentrations of leptin $(\mathrm{ng} / \mathrm{ml})$, LH and FSH (U/l), estradiol (pmol/l) and testosterone (nmol/l) before (open bars) and after (solid bars) $36 \mathrm{~h}$ of pulsatile GnRH administration. ${ }^{* \star} P<0.001$.

estradiol remained unchanged with $16.5 \pm 4.4 \mathrm{pmol} / \mathrm{l}$ before and $13.2 \pm 2.2 \mathrm{pmol} / \mathrm{l}$ after pulsatile GnRH. Multivariate analysis showed no effect of LH, FSH, testosterone or estradiol serum levels on leptin concentrations in the second standard GnRH test. Furthermore, no effect of gender, age, BMI or TANNER stage on the leptin response to pulsatile GnRH administration was observed. As expected, serum leptin concentrations were positively correlated with BMI $(r=0.51$, $P=0.019)$ in the study population.

\section{Buserelin acetate test}

Mean leptin concentrations remained unchanged in the nine patients receiving a single dose of buserelin acetate $(8.8 \pm 1.7$ vs $9.2 \pm 1.9 \mathrm{ng} / \mathrm{ml})$, although a slight increase in leptin concentrations was observed in some individuals, as displayed in Fig. 4 Children with $\mathrm{CD}$ showed a significant increase in LH levels $(2.0 \pm 0.3$ vs $4.5 \pm 0.57 \mathrm{U} / \mathrm{l}, P<0.01)$ and $\mathrm{FSH}$ levels (3.2 \pm 0.36 vs $6.5 \pm 0.9 \mathrm{U} / \mathrm{l}, \quad P=0.02)$ during the 24-h follow-up period. Data of patients who underwent the buserelin acetate test and 36-h stimulation with GnRH are displayed in Table 2.

\section{Discussion}

Leptin is known to play an important role in pubertal development, but whether it provides a trigger for pubertal development or acts as a permissive signal remains controversial. We show here that pulsatile GnRH stimulation results in an increase in circulating leptin concentrations in children with delayed pubertal development. This suggests that the changes in leptin levels are preceded by changes in GnRH pulsatility at the onset of puberty.

It is well known that concentrations of circulating leptin change during pubertal development (11-13). While leptin levels are similar in prepubertal boys and girls, a sexual dimorphism develops during puberty. After an initial increase, leptin levels decrease in male pubertal development, as leptin secretion is inhibited by testosterone; while in female puberty leptin levels steadily increase and are positively correlated to BMI $(12,13,17,20)$. Although there is evidence that serum leptin may peak before the onset of puberty and could therefore be a signal initiating pubertal development (14) this finding has not been confirmed by others (13), and animal studies show that leptin levels remain unchanged during pubertal development in primates and rats $(21-23)$. In humans, the main problem in addressing the question as to whether an initial leptin peak exists is to define the beginning of pubertal development. Biochemically, the onset of puberty is marked by increasing amplitudes of GnRH secretion of the hypothalamus during sleep $(10,18)$. These changes in hormonal status are not necessarily matched by physical changes in, for example, TANNER stages and therefore it is difficult to define the onset of puberty in a clinical study. In our study, we artificially recreated the onset of puberty by a 36-h stimulation of the pituitary with pulsatile GnRH, preceded and followed by a standard GnRH test. We observed higher leptin concentrations after the $36 \mathrm{~h}$ of pulsatile GnRH stimulation, indicating that leptin concentrations must have changed in response to the pulsatile GnRH stimulation. This positive leptin 

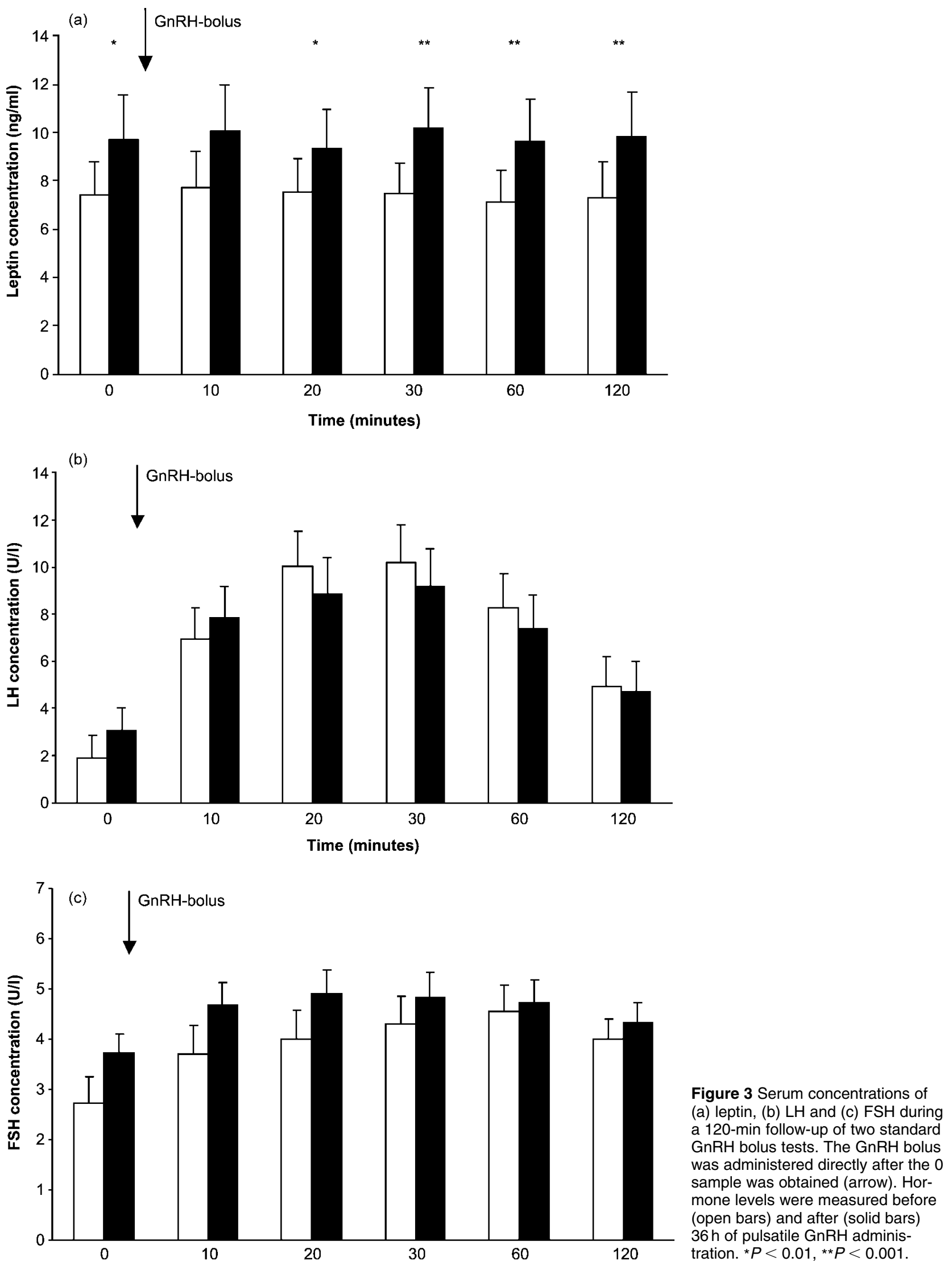


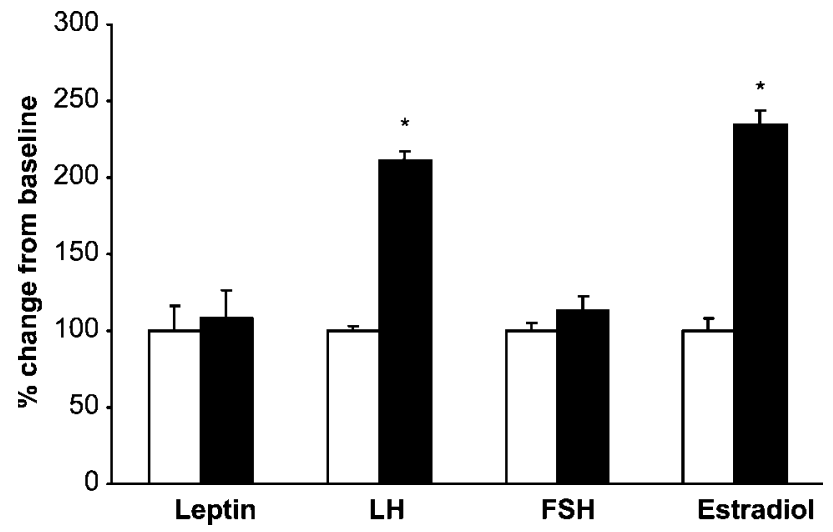

Figure 4 Change in serum concentrations of leptin, LH, FSH and estradiol before (open bars) and $24 \mathrm{~h}$ after (solid bars) administration of buserelin acetate. Hormone levels are calculated based on the values before buserelin acetate administration. ${ }^{\star} P<0.02$.

Table 2 Characteristics of patients undergoing pulsatile $\mathrm{GnRH}$ stimulation and single dose buserelin acetate test. Values are means \pm S.E.M. with range in parentheses.

\begin{tabular}{lcc}
\hline & $\begin{array}{c}\text { Pulsatile GnRH } \\
(n=16)\end{array}$ & $\begin{array}{c}\text { Buserelin acetate } \\
(n=8)\end{array}$ \\
\hline Gender (female/male) & $3 / 13$ & $2 / 6$ \\
HH/CD & $6 / 10$ & $4 / 4$ \\
Age (years) & $16 \pm 0.3$ & $15.5 \pm 0.5$ \\
& $(14.7-20.5)$ & $(13.1-16.7)$ \\
Bone age (years) & $13.9 \pm 0.6$ & $13 \pm 0.5$ \\
& $(9.8-15.4)$ & $(10-14.6)$ \\
BMI (kg/m $\left.{ }^{2}\right)$ & $22.9 \pm 1$ & $21.3 \pm 1.4$ \\
& $(16-30)$ & $(16-30)$ \\
LH (U/l) before GnRH & $1.91 \pm 0.45$ & $1.0 \pm 0.27$ \\
& $(0.04-7)$ & $(0.05-2.2)$ \\
LH (U/I) after GnRH & $3 \pm 0.9$ & $2.1 \pm 0.6$ \\
& $(0.3-16.8)$ & $(0.08-6.2)$ \\
FSH (U/I) before GnRH & $2.73 \pm 0.5$ & $2.0 \pm 0.5$ \\
& $(0.18-17.5)$ & $(0.1-4.6)$ \\
FSH (U/l) after GnRH & $3.7 \pm 0.4$ & $3.5 \pm 0.9$ \\
& $(1.6-7.3)$ & $(0.2-9.2)$ \\
Leptin (ng/ml) & $7.39 \pm 1.42$ & $7.5 \pm 1.4$ \\
before GnRH & $(0.8-8.4)$ & $(0.5-18.7)$ \\
Leptin (ng/ml) & $9.7 \pm 1.8$ & $8.3 \pm 1.6$ \\
after GnRH & $(0.8-24.7)$ & $(0.39-19.5)$ \\
\hline
\end{tabular}

response to pulsatile GnRH was not matched by changes in other hormones, such as LH, FSH or estradiol. Although serum levels of testosterone increased in most patients after priming with $\mathrm{GnRH}$, a stimulatory effect on leptin secretion is unlikely as testosterone is a potent inhibitor of leptin secretion in vivo and in vitro $(17,24)$. Multivariate statistical analysis revealed no influence of changes in serum testosterone on leptin serum levels in our patients.

Our data fit well into the hypothesis of leptin acting as a permissive factor for the onset of puberty. However, besides being a permissive factor, leptin could be part of a positive feedback loop, on the one hand stimulated by pulsatile GnRH and on the other hand allowing the $\mathrm{GnRH}$ amplitude to further increase, for example, by acting directly on the GnRH-secreting neurons. In rodents, a direct effect of leptin on GnRH-secreting neurons has been shown and it has been demonstrated that the GnRH-secreting neurons of rats express leptin receptors $(25,26)$. Up to now, however, these findings have been limited to animal models.

Our data were obtained from a group of children with delayed pubertal development due to $\mathrm{CD}$ or $\mathrm{HH}$. In delayed pubertal development a differentiation between $\mathrm{CD}$ and $\mathrm{HH}$ needs to be defined as different therapeutic regimes are indicated. A well-established test to differentiate between these two conditions is the 36-h GnRH stimulation test. In this test, two standard GnRH bolus tests are separated by a 36-h pulsatile injection of GnRH via an infusion pump. The LH increments in response to the standard GnRH bolus test after priming with pulsatile GnRH are lower in patients with $\mathrm{HH}$ than in patients with CD. The standard GnRH bolus tests alone failed to differentiate clearly between patients with $\mathrm{CD}$ and $\mathrm{HH}(27,28)$. Smals et al. (19) reported on a group of 33 patients (17 children with $\mathrm{CD}$ and 16 with $\mathrm{HH}$ ) who underwent pulsatile GnRH testing. They observed slight increases in LH and FSH and a twofold increase in testosterone levels after priming with GnRH. This increase was pronounced in the group of patients with $\mathrm{HH}$. Hormonal changes in our patients were consistent with these findings.

A few studies have investigated leptin levels in disturbed pubertal development. In these studies, leptin concentrations in children with precocious puberty were found to be normal for the pubertal stage, but decreased leptin concentrations were demonstrated in boys with CD (29-31). In our study population, leptin serum concentrations were positively correlated with BMI ( $r=0.51, P=0019)$ and did not differ between the group of children with $\mathrm{HH}$ and those with $\mathrm{CD}$.

We did not observe gender-specific differences in leptin responses to pulsatile GnRH stimulation; this could be explained by the fact that the patients were mainly TANNER stage 2, and a sexual dimorphism might not have been established at that point. However, gender-specific differences might also have been missed because of the relatively small number of girls in the group undergoing pulsatile GnRH stimulation.

Our data are in contradiction to a study investigating the effects of pulsatile GnRH administration in six male individuals with delayed sexual maturation. In this study by Giusti et al. (32), pulsatile GnRH was administered subcutaneously for 120 days in order to restore fertility. The authors did not observe changes in leptin concentrations or BMI but an increase in gonadotropins, testosterone and testicular volume. However, as leptin concentrations were measured only every 30 days in the study, it is conceivable that an initial increase in circulating leptin was missed. The subsequent increase in testosterone levels in the patients inhibited leptin secretion, as testosterone inhibits leptin secretion in vitro and in vivo $(17,24)$. 
To our surprise, leptin concentrations remained unchanged during the single dose buserelin acetate test. Although some patients showed a slight increase in leptin levels during the 24-h follow-up, this was neither a statistically significant nor a consistent finding within the patient group. We concluded that nonpulsatile $\mathrm{GnRH}$ administration does not affect leptin secretion. However, as the observation period in the group of patients undergoing the 36-h stimulation test was longer, we might have missed effects occurring after the $24 \mathrm{~h}$ following the buserelin administration.

Other studies investigating the role of non-pulsatile GnRH administration in humans have been performed in females undergoing hormone therapy for the induction of ovulation. In these studies, a parallel increase of estrogen and leptin after luteal phase stimulation with GnRH was observed, interpreted as a stimulatory effect of estrogen on leptin secretion (32-34). In our study, $\mathrm{GnRH}$ was administered short term (bolus or $36 \mathrm{~h}$ of pulsatile stimulation) and did not result in an increase in estrogen levels in the four female patients. The increase in leptin concentrations after the pulsatile GnRH stimulation was therefore not stimulated by estrogen in our study.

In conclusion, our data have demonstrated a stimulatory effect of pulsatile GnRH on circulating leptin in adolescents with delayed puberty. These findings support the view of leptin acting as a permissive factor for pubertal development and provide evidence that leptin is regulated by GnRH. Additional studies are needed to investigate leptin metabolism and the regulation of $\mathrm{GnRH}$ and leptin secretion during puberty.

\section{References}

1 Zhang Y, Proenca R, Maffei M, Barone M, Leopold L \& Friedman JM. Positional cloning of the mouse obese gene and its human homologue. Nature 1994372 425-432.

2 Friedman JM \& Halass JL. Leptin and the regulation of body weight in mammals. Nature 1998395 763-770.

3 Kalra SP, Dube MG, Pu S, Xu B, Horvath TL \& Kalra PS. Interacting appetite-regulating pathways in the hypothalamic regulation of body weight. Endocrine Reviews 199920 68-100.

4 Flier JS. Clinical review 94. What's in a name? In search of leptin's physiologic role. Journal of Clinical Endocrinology and Metabolism $1998 \mathbf{8 3} 1407-1413$.

5 Clement K, Vaisse C, Lahlou N, Cabrol S, Pelloux V, Cassuto D, Gourmelen M, Dina C, Chambaz J, Lacorte JM, Basdevant A, Bougneres P, Lebouc Y, Froguel P \& Guy-Grand B. A mutation in the human leptin receptor gene causes obesity and pituitary dysfunction. Nature $1998392398-401$.

6 Montague CT, Farooqi IS, Whitehead JP, Soos MA, Rau H, Wareham NJ, Sewter CP, Digby JE, Mohammed SN, Hurst JA, Cheetham CH, Earley AR, Barnett AH, Prins JB \& O'Rahilly S. Congenital leptin deficiency is associated with severe early-onset obesity in humans. Nature 1997 387 903-908.

7 Strobel A, Issad T, Camoin L, Ozata M \& Strosberg AD. A leptin missense mutation associated with hypogonadism and morbid obesity. Nature Genetics $199818213-215$.

8 Farooqi IS, Jebb SA, Langmack G, Lawrence E, Cheetham $\mathrm{CH}$, Prentice AM, Hughes IA, McCamish MA \& O'Rahilly S. Effects of recombinant leptin therapy in a child with congenital leptin deficiency. New England Journal of Medicine $1999341879-884$.

9 Kopp W, Blum WF, von Prittwitz S, Ziegler A, Lubbert H, Emons G, Herzog W, Herpertz S, Deter HC, Remschmidt H \& Hebebrand J. Low leptin levels predict amenorrhea in underweight and eating disordered females. Molecular Psychiatry 19972 335-340.

10 Grumbach MM. The neuroendocrinology of human puberty revisited. Hormone Research 200257 (Suppl 2) 2-14.

11 Clayton PE, Gill MS, Hall CM, Tillmann V, Whatmore AJ \& Price DA. Serum leptin through childhood and adolescence. Clinical Endocrinology $199746727-733$.

12 Horlick MB, Rosenbaum M, Nicolson M, Levine LS, Fedun B, Wang J, Pierson RN Jr \& Leibel RL. Effect of puberty on the relationship between circulating leptin and body composition. Journal of Clinical Endocrinology and Metabolism $2000 \quad 85$ 2509-2518.

13 Ahmed ML, Ong KK, Morrell DJ, Cox L, Drayer N, Perry L, Preece MA \& Dunger DB. Longitudinal study of leptin concentrations during puberty sex differences and relationship to changes in body composition. Journal of Clinical Endocrinology and Metabolism $199984899-905$.

14 Mantzoros CS, Flier JS \& Rogol AD. A longitudinal assessment of hormonal and physical alterations during normal puberty in boys. V. Rising leptin levels may signal the onset of puberty. Journal of Clinical Endocrinology and Metabolism 199782 1066-1070.

15 Blum WF, Englaro P, Hanitsch S, Juul A, Hertel NT, Muller J, Skakkebaek NE, Heiman ML, Birkett M, Attanasio AM, Kiess W \& Rascher W. Plasma leptin levels in healthy children and adolescents: dependence on body mass index, body fat mass, gender, pubertal stage and testosterone. Journal of Clinical Endocrinology and Metabolism 199782 2904-2910.

16 Garcia-Mayor RV, Andrade MA, Rios M, Lage M, Dieguez C \& Casanueva FF. Serum leptin levels in normal children: relationship to age, gender, body mass index, pituitary-gonadal hormones, and pubertal stage. Journal of Clinical Endocrinology and Metabolism 199782 2849-2855.

17 Wabitsch M, Blum WF, Muche R, Braun M, Hube F, Rascher W, Heinze E, Teller $W$ \& Hauner H. Contribution of androgens to the gender difference in leptin production in obese children and adolescents. Journal of Clinical Investigation 1997100 808-813.

18 Boyar RM, Wu RHK, Kapen S, Hellmann L, Weitzmann ED \& Finkelstein JW. Synchronization of augmented luteinizing hormone secretion with sleep during puberty. New England Journal of Medicine 1972187 582-586.

19 Smals AG, Hermus AR, Boers GH, Pieters GF, Benraad TJ \& Kloppenborg PW. Predictive value of luteinizing hormone releasing hormone (LHRH) bolus testing before and after 36-hour pulsatile LHRH administration in the differential diagnosis of constitutional delay of puberty and male hypogonadotropic hypogonadism. Journal of Clinical Endocrinology and Metabolism 199478 602-608.

20 Vogel G. Leptin: a trigger for puberty? Science $1996 \mathbf{2 7 4}$ $1466-1467$.

21 Mann DR, Akinbami MA, Gould KG \& Castracane VD. A longitudinal study of leptin during development in the male rhesus monkey: the effect of body composition and season on circulating leptin levels. Biology of Reproduction 200062 285-291.

22 Plant TM \& Durrant AR. Circulating leptin does not appear to provide a signal for triggering the initiation of puberty in the male rhesus monkey (Macaca mulatta). Endocrinology 1997138 4505-4508.

23 Cheung CC, Thornton JE, Nurani SD, Clifton DK \& Steiner RA. A reassessment of leptin's role in triggering the onset of puberty in the rat and mouse. Neuroendocrinology 2001 74 12-21.

24 Adan L, Bussieres L, Trivin C, Souberbielle JC \& Brauner R. Effect of short-term testosterone treatment on leptin concentrations in boys with pubertal delay. Hormone Research 199952 109-112.

25 Magni P, Vettor R, Pagano C, Calcagno A, Beretta E, Messi E, Zanisi M, Martini L \& Motta M. Expression of a leptin receptor in immortalized GnRH-secreting neurons. Endocrinology 1999 $1401581-1585$. 
26 Lebrethon MC, Vandersmissen E, Gerard A, Parent AS, Junien JL \& Bourguignon JP. In vitro stimulation of the prepubertal rat gonadotropin-releasing hormone pulse generator by leptin and neuropeptide $\mathrm{Y}$ through distinct mechanisms. Endocrinology $20001411464-1469$.

27 Sizonenko PC. Preadolescent and adolescent endocrinology physiology and pathophysiology. II Hormonal changes during abnormal pubertal development. American Journal of Diseases in Children $1978132797-805$.

28 Kelch RP, Hopwood NJ \& Marshall JC. Diagnosis of gonadotropin deficiency in adolescents: limited usefulness of a standard gonadotropin-releasing hormone test in obese boys. Journal of Pediatrics $198097820-824$.

29 Chemaitilly W, Trivin C, Adan L, Gall V, Sainte-Rose C \& Brauner R. Central precocious puberty clinical and laboratory features. Clinical Endocrinology $2001 \mathbf{5 4} 289-294$.

30 Verrotti A, Basciani F, Trotta D, De Simone M, Morgese G \& Chiarelli F. Serum leptin levels in girls with precocious puberty. Diabetes, Nutrition and Metabolism 200316 125-129.
31 Gill MS, Hall CM, Tillmann V \& Clayton PE. Constitutional delay in growth and puberty (CDGP) is associated with hypoleptinemia. Clinical Endocrinology 199950 721-726.

32 Giusti M, Guido R, Valenti S \& Giordano G. Serum leptin levels in males with delayed puberty during short-term pulsatile $\mathrm{GnRH}$ administration. Journal of Endocrinological Investigation 199922 $6-11$.

33 Yamada M, Irahara M, Tezuka M, Murakami T, Shima K \& Aono T. Serum leptin profiles in the normal menstrual cycles and gonadotropin treatment cycles. Gynecologic and Obstetric Investigation $200049119-123$.

34 Zhao Y, Kreger DO \& Brannian JD. Serum leptin concentrations in women during gonadotropin stimulation cycles. Journal of Reproductive Medicine $2000 \mathbf{4 5} 121-125$.

Received 25 November 2003

Accepted 12 February 2004 